\title{
Effects of Dietary Aged Maize with Oxidized Fish Oil on Growth Performance, Antioxidant Capacity and Intestinal Health in Weaned Piglets
}

\author{
Bin Luo, Daiwen Chen $₫$, Gang Tian, Ping Zheng, Jie Yu, Jun He $₫$, Xiangbin Mao $₫$, Yuheng Luo, \\ Junqiu Luo, Zhiqing Huang ${ }^{(1)}$ and Bing $\mathrm{Yu}^{*}$ (1) \\ Institute of Animal Nutrition, Sichuan Agricultural University, Chengdu 611130, China \\ * Correspondence: ybingtian@163.com
}

Received: 23 July 2019; Accepted: 26 August 2019; Published: 29 August 2019

check for updates

Simple Summary: In China, large quantities of maize are stored in grain depots for two years or more to mitigate the risk of natural disasters impacting feed supplies. However, it is unknown whether the use of long-term stored maize in diets will impair growth performance of piglets, and whether additional dietary oxidants would further exacerbate the effects. This study investigates the effects of dietary aged maize with the supplementation of different levels of oxidized fish oil on growth performance, nutrient digestibility, serum antioxidant activity and gut health in piglets and tries to provide a theoretical foundation for the better use of aged maize in swine production. The results of this study showed that aged maize had no significant effect on growth performance, diarrhea and nutrient digestibility of the piglets, but it did reduce serum antioxidant capacity. When oxidized fish oil was added, aged maize reduced serum antioxidant capacity further, inhibited the expressions of genes related to intestinal nutrient transport, promoted intestinal inflammation, and also reduced the apparent total tract digestibility (ATTD) of nutrients, increased diarrhea and finally reduced the growth performance of piglets. Thus, the use of aged maize in the diet of the piglets may be not feasible, especially when other oxidation-inducing factors existed, which would exacerbate the negative effects of the aged maize.

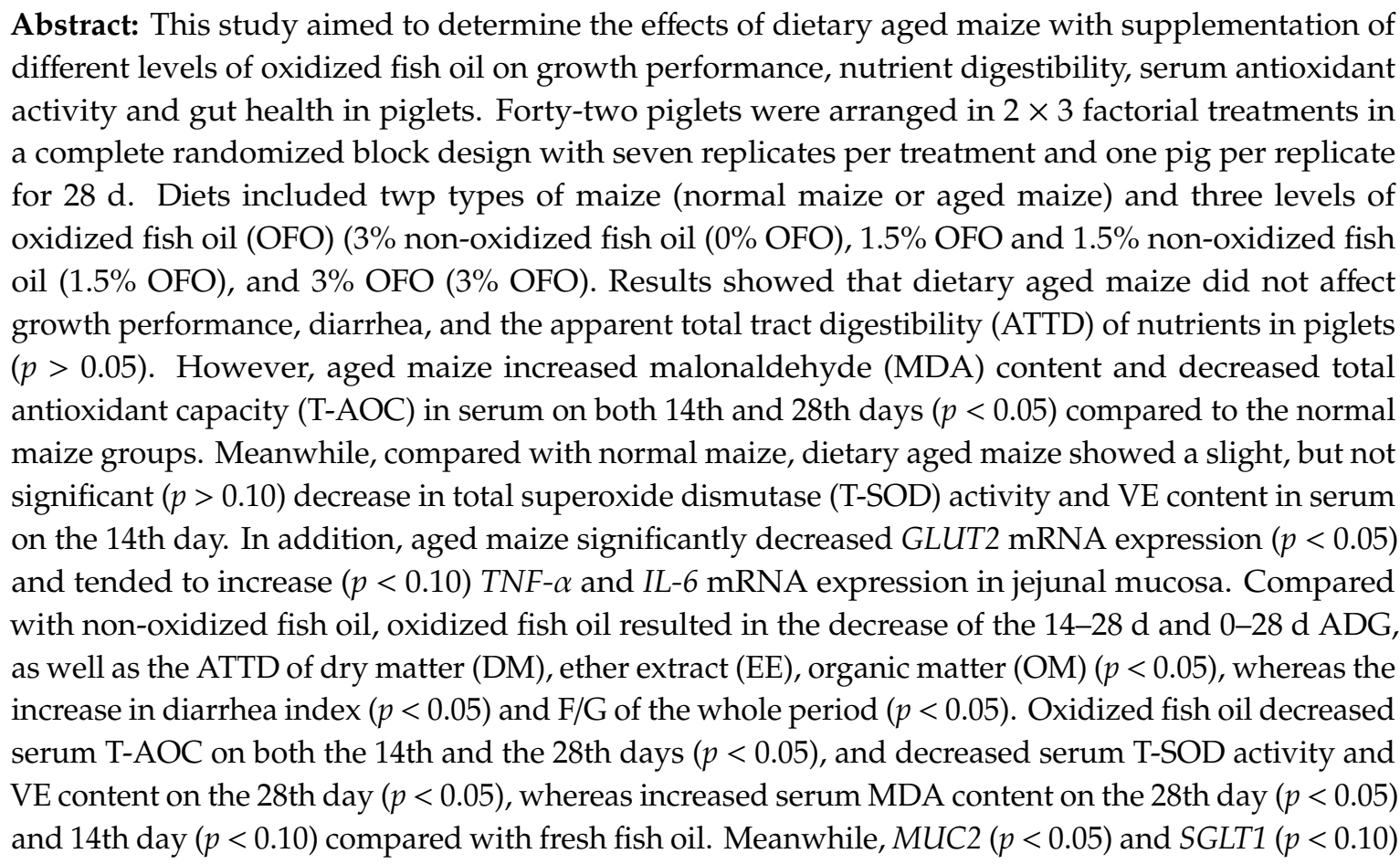


mRNA expression in jejunal mucosa were decreased compared with non-oxidized fish oil. In addition, dietary oxidized fish oil tended to decrease 14-28 d ADFI and the ATTD of $\mathrm{CP}(p<0.10)$, and piglets fed oxidized fish oil significantly decreased 14-28 d ADFI, the ATTD of CP, GLUT2 and SGLT1 mRNA expressions in jejunal mucosa when piglet also fed with aged maize $(p<0.05)$. Collectively, these results indicated that dietary oxidized fish oil decreased growth performance and nutrients digestibility of piglets fed with aged maize. This nutrient interaction may be mediated by inhibiting intestinal nutrient transporter, inducing intestinal inflammation, and reducing antioxidant capacity.

Keywords: aged maize; oxidized fish oil; growth performance; nutrient digestibility; antioxidant capacity; intestinal health; weaning piglets

\section{Introduction}

Maize is a primary source of energy and accounts for the highest proportion of ingredients in most livestock diets [1]. Large quantities of maize were stored for two years or more in grain depots to be prepared for the potential event of natural disasters. Unfortunately, a significant quantity of maize was lost due to biological, chemical and physical factors during these long storage times [2,3]. Storage time increases the contents of oxidation of lipid and fatty acid and also increases the fat acidity value (FAV) of maize $[4,5]$. Free fatty acids in maize are easily oxidized, producing lipid hydroperoxides, which affects catalase (CAT) and peroxidase (POD) activities [6]. The addition of dietary aged maize increases the amount of exogenous reactive oxygen species (ROS) and leads to lipid peroxidation, which may cause oxidative stress with negative impacts on animal health [7-10]. However, Mitchell and Beadles [11] reported that when maize was stored from 730 to $1020 \mathrm{~d}$, there was no consistent or significant deterioration in the digestibility or the biological value of the maize when fed to rats. No effect was observed on the growth rate of rats fed maize which was stored for as long as six years [12]. Bartov [13] found that maize stored for 110 months in covered galvanized iron cans did not lead to any change in the chemical composition of the grains, except for a significant increase in lysine and a decrease in valine contents. Moreover, the nitrogen-corrected apparent metabolizable energy content for broiler chicks was not affected significantly by storage duration. These findings are not consistent with the negative effects of aged maize, that may lead to decreased growth performance with an increase in diarrhea in animals [14]. However, those previous studies utilized poultry and rats, and the effect of aged maize in piglets has not yet been studied. Most often, piglets are exposed to various complex stress, such as feed lipid oxidation or feed mildew [15]. To the best of our knowledge, there was no published reported the effects of feeding aged maize with or without oxidized oil in piglet diets, and whether the oxidized oil may exacerbate the effects of aged maize on piglets. Moreover, fish oil is rich in polyunsaturated fatty acids (PUFA) and which are easily oxidized [16]. Therefore, our objective was to evaluate the effects of aged maize on growth performance, nutrient digestibility, antioxidant activity and intestinal health of weaning piglets. Furthermore, we aimed to assess whether the effects of aged maize was exacerbated by adding oxidized fish oil at different levels.

\section{Materials and Methods}

All animal experiments were approved by the Animal Protection and Utilization Committee of Sichuan Agricultural University (Chengdu, China) [17]. The experiment described here was conducted at the Animal Experiment Center of Sichuan Agriculture University (Yaan, China).

\subsection{Maize Samples}

Aged maize and normal maize were obtained from National barns, China, after being stored for either five or 0.5 years. The maize was ground through a $1 \mathrm{~mm}$ screen using a hammer mill and then moisture (Method 930.15), lipids ether extracted (EE) (Method 920.39), crude ash assayed (Ash) 
(Method 942.05) and crude protein (CP) (Method 984.13) contents measured according to methods published by AOAC [18]. The amino acid content in maize was determined by automatic amino acid analyzer L-8900 (Japan Hitachi co., Ltd., Tokyo, Japan) according to Qiang, et al. [19]. Fatty acid content was determined using gas chromatography GC-17A (Shimadzu, Kyoto, Japan) according to Querijero, et al. [20]. Fatty acid value (FAV) was determined as potassium hydroxide to neutralize the acids in a100 gram of sample by method GB/T 20570-2015 [21]. The MDA content, CAT and POD activities were measured using assay kits (Jiancheng Bioengineering Institute of Biological Engineering, Nanjing, China).

\subsection{Animals and Diets}

A total of forty-two $26 \pm 1$-d-old Duroc $\times$ Landrace $\times$ Yorkshire (DLY) cross-bred piglets (initial body weight $7.95 \pm 0.56 \mathrm{~kg}$ ) were allocated to six groups with seven piglets per group. The study was carried out as a $2 \times 3$ factorial experiment with two types of maize (normal maize or aged maize) and three levels of oxidized fish oil (OFO) (3\% non-oxidized fish oil ( $0 \%$ OFO), $1.5 \%$ OFO and $1.5 \%$ non-oxidized fish oil (1.5\% OFO), and 3\% OFO (3\% OFO)). Diets were formulated (Table 1) to meet the requirements of 10- to 20- kg pigs as established by the NRC (2012) [22]. All pigs were housed in individual metabolism cages $(0.7 \mathrm{~m} \times 1.5 \mathrm{~m} \times 1 \mathrm{~m})$ and were given ad libitum access to fresh water and feed. Room temperature was maintained at $25-28{ }^{\circ} \mathrm{C}$, and relative humidity was maintained between 55-65\%. Pigs were hand-fed three times per day (08:00, 14:00 and 20:00) to make sure that fresh feed was available.

Table 1. Composition and nutrient levels of the basal diet (air-dry basis \%).

\begin{tabular}{cccc}
\hline Items & Content & Nutrient Levels ${ }^{3}$ & Content \\
\hline Maize & 61.00 & DE (Mcal/kg) & 3.51 \\
Soybean meal & 17.71 & CP & 18.82 \\
Fish meal & 4.50 & $\mathrm{Ca}$ & 0.75 \\
Whey powder (Low protein) & 5.00 & $\mathrm{TP}$ & 0.56 \\
Soybean protein concentrate & 4.00 & $\mathrm{AP}$ & 0.37 \\
Fish oil & 3.00 & Digestible Lys & 1.30 \\
Sucrose & 1.00 & Digestible Met + Cys & 0.66 \\
Glucose & 1.50 & Digestible Thr & 0.77 \\
Limestone & 0.87 & Digestible Trp & 0.21 \\
CaHPO 4 & & \\
NaCl & 0.36 & & \\
L-Lys $\cdot$ HCl (78\%) & 0.20 & & \\
DL-Met & 0.26 & & \\
L-Thr $(98.5 \%)$ & 0.06 & & \\
Chloride choline $(50 \%)$ & 0.02 & & \\
Vitamin premix ${ }^{1}$ & 0.15 & & \\
Mineral premix ${ }^{2}$ & 0.03 & & \\
Total & 0.30 & & \\
\hline
\end{tabular}

\footnotetext{
${ }^{1}$ The vitamin premix provided the following per kg of the diet: VA $8000 \mathrm{IU}, \mathrm{VD}_{3} 2000 \mathrm{IU}, \mathrm{VE} 20 \mathrm{IU}, \mathrm{VB}_{1} 1.5 \mathrm{mg}, \mathrm{VB}_{2}$ $5.6 \mathrm{mg}, \mathrm{VB}_{12} 0.02 \mathrm{mg}, \mathrm{VB}_{6} 1.5 \mathrm{mg}$, D-D-Calcium Pantothenate $10 \mathrm{mg}$, Nicotinic acid $15 \mathrm{mg}$, Biotin $0.1 \mathrm{mg}$, Folic acid $0.6 \mathrm{mg}$. ${ }^{2}$ The mineral premix provided the following per kg of the diet: $\mathrm{Fe}$ (as ferrous sulfate monohydrate) $100 \mathrm{mg}$, $\mathrm{Cu}$ (as copper sulfate pentahydrate) $125 \mathrm{mg}$, Zn (as zinc sulfate) $100 \mathrm{mg}$, Mn (as manganese sulfate) $20 \mathrm{mg}$, I (as potassium iodide) $0.3 \mathrm{mg}$, Se (as sodium selenite) $0.3 \mathrm{mg} .{ }^{3}$ Nutrient levels of diets were calculated by the values in Chinese feed database.
}

\subsection{Oxidized Fish Oil Preparation}

Fresh fish oil was mixed with $143.54 \mathrm{mg} / \mathrm{kg}$ of $\mathrm{FeSO}_{4} \cdot 7 \mathrm{H}_{2} \mathrm{O}, 58.94 \mathrm{mg} / \mathrm{kg}$ of CuSO $\mathrm{Cu}_{4} \cdot 5 \mathrm{H}_{2} \mathrm{O}, 600 \mathrm{mg} / \mathrm{kg}$ of $\mathrm{H}_{2} \mathrm{O}_{2}$ and $0.3 \%$ of $\mathrm{H}_{2} \mathrm{O}$ by volume, and heated to a constant temperature of $37 \pm 1^{\circ} \mathrm{C}$. Throughout the heating process, air was continuously bubbled through the oil [23]. The degree of oxidation of the fish oil was monitored by the determination of the peroxide value (POV) every $24 \mathrm{~h}$.

After 13 days of oxidation, when the POV reached of $120.85 \mathrm{meq} \mathrm{O}_{2} / \mathrm{kg}$, which was determined as the end point of oxidation. The POV of the fresh fish oil was $4.08 \mathrm{meq} \mathrm{O}_{2} / \mathrm{kg}$. POV were determined according the method described by method GB 5009.227-2016 by potassium iodide titration [24]. The oxidized fish oil was then collected and stored at $-20{ }^{\circ} \mathrm{C}$ until use. 


\subsection{Sample Collection}

At the beginning of the trial, representative maize and feed samples of each group were sampled and stored at $-20{ }^{\circ} \mathrm{C}$ for chemical analyses. $\mathrm{Cr}_{2} \mathrm{O}_{3}(0.3 \%)$ was included in all diets as an indigestible marker. After feeding diets with $\mathrm{Cr}_{2} \mathrm{O}_{3}$ from day 24 to day 27 of the experiment, fresh fecal samples were collected from all pigs. Each pig's daily excreta was weighed, and $10 \mathrm{~mL}$ of a $10 \% \mathrm{H}_{2} \mathrm{SO}_{4}$ solution was added to each $100 \mathrm{~g}$ of wet fecal sample and stored at $-20^{\circ} \mathrm{C}$. At the end of this $4 \mathrm{~d}$ period, all fecal samples of each pig were dried in an oven $\left(65^{\circ} \mathrm{C}\right.$ for $\left.72 \mathrm{~h}\right)$, ground up, and passed through a 1-mm sieve, then stored at $-20^{\circ} \mathrm{C}$ for later chemical analyses.

Piglets were fasted for 12-h prior to the morning of day 28, at which time blood samples were collected from the anterior juguldfar cava into vacuum tubes without anticoagulant. Blood samples were centrifuged at $3500 \times g$ for $15 \mathrm{~min}$ at $4{ }^{\circ} \mathrm{C}$, and serum was separated and stored at $-20^{\circ} \mathrm{C}$ for further analyses. Pigs were then euthanized by intravenous injection of sodium pentobarbital $(90 \mathrm{mg} / \mathrm{kg} \mathrm{BW})$. The abdomen was immediately opened and the jejunum was then opened longitudinally and washed with cold saline solution. Mucosal samples from mid- jejunum were dissected, snap-frozen in liquid nitrogen, and stored at $-80^{\circ} \mathrm{C}$ for further analyses.

\subsection{Mycotoxin Content of Maize and Diets}

Normal maize, aged maize and diet samples were ground using a mill grinder (Retsch ZA 100; Restsch GmbH and Co., K. g., Haan, Germany) and passed through a 0.5-mm screen prior to analyses. Aflatoxin B1 (AFB1), zearalenone (ZEN), deoxynivalenol (DON), fumonisin (FB), ochratoxins (OTA) were measured using the national standard methods NY/T 2071-2011 [25], GB/T 30956-2014 [26], NY/T 1970-2010 [27] and GB/T 30957-2014 [28] by HPLC and a combination of gas chromatography or mass spectrometry methods [29].

\subsection{Growth Performance}

Body weights (BW) of pigs were individually measured after 12-h fasting on the mornings of day 0 , day 14 and day 28 of the feeding trial, and feed intake per pen was collected daily throughout the trial to calculate average daily feed intake (ADFI), average daily gain (ADG) and ADFI/ADG (F/G).

\subsection{Diarrhea Rate and Diarrhea Index}

The pigs' stool was observed at the same time of each morning and night by one observers blinded to treatments during the entire experimental period based on the method described by Yuan, et al. [30]. Briefly, fresh excreta from each pig was assessed visually with a score from 0 to 3 ( $0=$ hard bar/hard granulous, $1=$ soft/forming, $2=$ dense/not formed, $3=$ fluid/not formed). The occurrence of diarrhea was defined as production of feces at level 2 or 3 . Diarrhea frequency was then calculated as follows: Diarrhea rate $(\%)=($ total number of pigs per pen with diarrhea $) /($ number of pigs per group $\times 28 \mathrm{~d}) \times$ 100; Diarrhea index $=$ SUM diarrhea score/(number of pigs per group $\times 28 \mathrm{~d}$ ).

\subsection{The Apparent Total Tract Digestibility}

Diet and fecal samples were analyzed for $\mathrm{DM}, \mathrm{CP}, \mathrm{EE}$, and Ash according to the procedures described by AOAC [18]. Moreover, organic matter (OM) was calculated by 100 minus the content of ash by AOAC [18]. The apparent total tract digestibility (ATTD) of DM, CP, EE, Ash, and OM were measured using $\mathrm{Cr}_{2} \mathrm{O}_{3}$ as an exogenous indicator. Concentration of $\mathrm{Cr}$ in the digested samples was measured using flame atomic absorption spectroscopy method AOAC [18]. The ATTD was calculated according to the following equation [31]: ATTD $(\%)=100-[(\mathrm{Cri} / \mathrm{Cro}) \times(\mathrm{No} / \mathrm{Ni})]$, in which Cri is the chromium concentration of diet; Cro is the chromium concentration of excreta; No is the nutrient concentration of excreta; $\mathrm{Ni}$ is the nutrient concentration in the diet. 


\subsection{Antioxidant Capacity in Serum}

Serum total antioxidant capacity (T-AOC) with the colorimetric method, activities of total superoxide dismutase (T-SOD) with the hydroxylamine method, catalase (CAT) with the ammonium molybdate method and glutathione peroxidase (GSH-Px) with colorimetric method, contents of malondialdehyde (MDA) with the TBA method and vitamin E (VE) with the colorimetric method were measured using respective assay kits (Jiancheng Bioengineering Institute of Biological Engineering, Nanjing, China) with UV-VIS Spectrophotometer (UV1100, MAPADA, Shanghai, China) according to the manufacturer's instructions.

\subsection{Real-Time Quantitation PCR}

Total RNA was extracted from jejunal mucosa using Trizol reagent (TaKaRa, Dalian, China) following the manufacturer's instructions. The concentration and purity of RNA was analyzed spectrophotometrically (Beckman Coulter DU800; Beckman Coulter Inc., Pasadena, CA, USA). The integrity of RNA was checked by denaturing agarose gel electrophoresis. RNA samples were used to synthesize the cDNA using PrimeScripte RT reagent kit (Takara Shuzo Co., Ltd., Kusatsu, Japan) according to the manufacturer's instructions. The cDNA was diluted and used as a PCR template to evaluate gene expression. The primers were synthesized commercially by Life Technologies Limited, and were listed in Table 2. Real-time PCR for quantification of Na+ glucose transporter 1 (SGLT1), Glucose transporter 2 (GLUT2), Zonulaoccludens 1 (ZO-1), Occludin (OCLN), Claudin 1 (CLDN1), Mucin1 (MUC1), Mucin2 (MUC2), Tumor necrosis factor- $\alpha$ (TNF- $\alpha$ ), Interleukin $1 \beta$ (IL-1 $\beta)$, Interleukin 6 (IL-6), Interleukin 10 (IL-10) were performed on an Opticon DNA Engine (Bio-Rad) using SYBR Premix Ex TaqTM kits (TaKaRa) under the following conditions: pre-denaturation at $95^{\circ} \mathrm{C}$ for $30 \mathrm{~s}$ and forty cycles of denaturation at $95^{\circ} \mathrm{C}$ for $5 \mathrm{~s}$, annealing at $60^{\circ} \mathrm{C}$ for $30 \mathrm{~s}$ and extension at $72{ }^{\circ} \mathrm{C}$ for $60 \mathrm{~s}$. A dissociation curve was constructed at the end of the reaction to ensure that only one amplication was formed. $\beta$-actin was chosen as the reference gene, and the relative expression ratio of the target genes in comparison with the reference gene was calculated as described by Pfaffl [32]. Mean Ct of each gene was determined from double measurements and normalized with the mean Ct of $\beta$-actin, a control gene.

Table 2. Primer sequences used for real-time PCR.

\begin{tabular}{|c|c|c|c|}
\hline Gene & Primer Sequence $\left(5^{\prime}-3^{\prime}\right)$ & $\begin{array}{l}\text { Product } \\
\text { Length(bp) }\end{array}$ & $\begin{array}{c}\text { GeneBank } \\
\text { Accession No. }\end{array}$ \\
\hline$\beta$-actin & $\begin{array}{l}\text { Forward: TCCATCGTCCACCGCAAATG } \\
\text { Reverse: TTCAGGAGGCTGGCATGAGG }\end{array}$ & 124 & XM_003357928.4 \\
\hline SGLT1 ${ }^{1}$ & $\begin{array}{l}\text { Forward: AGAAGGGCCCCAAAATGACC } \\
\text { Reverse: TGTTCACTACTGTCCGCCAC }\end{array}$ & 96 & NM_001164021.1 \\
\hline GLUT2 & $\begin{array}{l}\text { Forward: GACACGTTTTGGGTGTTCCG } \\
\text { Reverse: GAGGCTAGCAGATGCCGTAG }\end{array}$ & 156 & NM_001097417.1 \\
\hline CLDN1 & $\begin{array}{l}\text { Forward: TCTTAGTTGCCACAGCATGG } \\
\text { Reverse: CCAGTGAAGAGAGCCTGACC }\end{array}$ & 106 & NM001244539 \\
\hline OCLN & $\begin{array}{l}\text { Forward: CTACTCGTCCAACGGGAAAG } \\
\text { Reverse: ACGCCTCCAAGTTACCACTG }\end{array}$ & 158 & NM_001163647.2 \\
\hline $\mathrm{ZO}-1$ & $\begin{array}{l}\text { Forward: CAGCCCCCGTACATGGAGA } \\
\text { Reverse: GCGCAGACGGTGTTCATAGTT }\end{array}$ & 114 & XM_005659811 \\
\hline MUC1 & $\begin{array}{l}\text { Forward: GTGCCGCTGCCCACAACCTG } \\
\text { Reverse: AGCCGGGTACCCCAGACCCA }\end{array}$ & 141 & XM_001926883.4 \\
\hline MUC2 & $\begin{array}{l}\text { Forward: GGTCATGCTGGAGCTGGACAGT } \\
\text { Reverse: TGCCTCCTCGGGGTCGTCAC }\end{array}$ & 181 & XM_003122394.1 \\
\hline$I L-1 \beta$ & $\begin{array}{l}\text { Forward: CAGCTGCAAATCTCTCACCA } \\
\text { Reverse: TCTTCATCGGCTTCTCCACT }\end{array}$ & 112 & NM_214055.1 \\
\hline
\end{tabular}


Table 2. Cont.

\begin{tabular}{cccc}
\hline Gene & Primer Sequence $\left(5^{\prime}-\mathbf{3}^{\prime}\right)$ & $\begin{array}{c}\text { Product } \\
\text { Length(bp) }\end{array}$ & $\begin{array}{c}\text { GeneBank } \\
\text { Accession No. }\end{array}$ \\
\hline TNF- $\alpha$ & $\begin{array}{c}\text { Forward: CGTGAAGCTGAAAGACAACCAG } \\
\text { Reverse: GATGGTGTGAGTGAGGAAAACG }\end{array}$ & 121 & NM_214022.1 \\
\hline IL-6 & $\begin{array}{c}\text { Forward: TTCACCTCTCCGGACAAAAC } \\
\text { Reverse: TCTGCCAGTACCTCCTTGCT }\end{array}$ & 122 & NM_001252429.1 \\
\hline \multirow{2}{*}{$I L-10$} & $\begin{array}{c}\text { Forward: TAATGCCGAAGGCAGAGAGT } \\
\text { Reverse: GGCCTTGCTCTTGTTTTCAC }\end{array}$ & 134 & NM_214041.1 \\
\hline
\end{tabular}

$1 \overline{\text { SGLT1 }=\text { Na+ glucose transport protein-1; GLUT2 = glucose transporter-2; ZO-1 = Zonulaoccludens } 1 ; \text { OCLN }}$ $=$ Occludin; $C L D N 1=$ Claudin $1 ; M U C 1=$ Mucin1; MUC2 $=$ Mucin2, TNF- $\alpha=$ Tumor necrosis factor $-\alpha ; I L-1 \beta=$ Interleukin $1 \beta ; I L-6=$ Interleukin $6 ; I L-10=$ Interleukin 10.

\subsection{Statistical Analyses}

All data were analyzed as a $2 \times 3$ factorial with the general linear model for analysis of variance using SPSS (Version 22.0; IBM, Inc., Chicago, IL, USA). The model factors included the effects of maize (normal maize or aged maize), oxidized fish oil levels $(0 \%, 1.5 \%$ or $3 \%$ ), and their interaction. $p<0.05$ was considered to indicate a significant difference and values between 0.05 and 0.10 to indicate a trend. Variable means for treatments showing significant differences in ANOVA were separated by Duncan's test $(p<0.05)$. Data for diarrhea rate and diarrhea index were analyzed by using a non-parametric test. Values were expressed as means with their standard errors.

\section{Results}

\subsection{Physical and Chemical Properties of Aged Maize and Normal Maize}

The data of physical and chemical properties of aged maize and normal maize are shown in Table 3. The moisture content of aged maize was slightly lower than that of normal maize, while the contents of EE, Ash and CP were slightly higher than that of normal maize. The composition of amino acids and fatty acids in aged maize are similar to those in normal maize. There were large differences in CAT and POD activities as well as in FAV and MDA content. Moreover, aged maize showed a greater decrease in CAT and POD activities and a greater increase in fat acid value and MDA content compared with normal maize.

Table 3. Phytochemical properties of aged maize and normal maize (air dry).

\begin{tabular}{ccc}
\hline Items & Normal Maize & Aged Maize \\
\hline Moisture (\%) & 13.83 & 12.36 \\
EE $^{1}(\%)$ & 3.77 & 4.67 \\
Ash (\%) $_{\text {CP (\%) }}$ & 1.40 & 1.83 \\
& 7.27 & 8.74 \\
\hline Glu & Amino acid (\%) & \\
Gly & 1.60 & 1.87 \\
Ala & 0.35 & 0.39 \\
Cys & 0.63 & 0.75 \\
Val & 0.06 & 0.04 \\
Met & 0.39 & 0.42 \\
Ile & 0.13 & 0.13 \\
Leu & 0.32 & 0.31 \\
Tyr & 1.04 & 1.19 \\
Phe & 0.29 & 0.34 \\
Lys & 0.46 & 0.46 \\
His & 0.30 & 0.26 \\
Arg & 0.24 & 0.26 \\
Pro & 0.36 & 0.35 \\
\hline
\end{tabular}


Table 3. Cont.

\begin{tabular}{ccc}
\hline \multicolumn{1}{c}{ Items } & Normal Maize & Aged Maize \\
\hline Fatty acid (\% of total fatty acid) & \\
\hline Myristic acid (C16:0) & 12.96 & 12.67 \\
Palmitic acid (C18:0) & 1.56 & 1.75 \\
Arachidic acid (C20:0) & 0.37 & 0.35 \\
Oleic acid (C18:1n-9) & 26.78 & 24.48 \\
Eicosenoic acid (C20:1n-9) & 0.30 & 0.24 \\
Linoleic acid (C18:2n-6) & 55.98 & 58.36 \\
$\alpha$-Linolenic acid (C18:3n-3) & 1.50 & 0.99 \\
FAV (mg KOH/100g) & 65.37 & 128.25 \\
MDA (nmol/mg prot) & 8.31 & 22.37 \\
POD (U/mg prot) & 15.19 & 3.05 \\
CAT (U/mg prot) & 8.53 & 1.17
\end{tabular}

${ }^{1} \mathrm{EE}=$ ether extract; $\mathrm{Ash}=$ crude ash; $\mathrm{CP}=$ crude protein; FAV = fatty acid value; MDA = malondialdehyde; $\mathrm{POD}=$ peroxidase; $\mathrm{CAT}=$ catalase.

\subsection{Mycotoxin Content of Maize and Diets}

The level and type of mycotoxins in maize and diets are shown in Table 4. The contents of AFB1, ZEA, DON, FB, OTA in maize and diets were within GB 13078-2017 [33].

Table 4. Mycotoxin content of maize and diets $(\mu \mathrm{g} / \mathrm{kg})$.

\begin{tabular}{|c|c|c|c|c|c|c|c|c|c|c|}
\hline \multirow{2}{*}{ Items } & \multirow{2}{*}{$\begin{array}{c}\text { Normal } \\
\text { Maize }\end{array}$} & \multirow{2}{*}{$\begin{array}{l}\text { Aged } \\
\text { Maize }\end{array}$} & \multirow{2}{*}{$\begin{array}{l}\text { Limits in } \\
\text { Maize }^{4}\end{array}$} & \multicolumn{3}{|c|}{ Normal Maize Diets } & \multicolumn{3}{|c|}{ Aged Maize Diets } & \multirow{2}{*}{$\begin{array}{c}\text { Limits in } \\
\text { Diets }\end{array}$} \\
\hline & & & & $0^{1}$ & 1.5 & 3 & 0 & 1.5 & 3 & \\
\hline AFB1 $^{2}$ & $\mathrm{ND}^{3}$ & ND & 50 & ND & ND & ND & ND & ND & ND & 10 \\
\hline ZEA & ND & 18.7 & 500 & 27.5 & 26.7 & 23.6 & 44.7 & 35.1 & 40.1 & 150 \\
\hline $\mathrm{DON}$ & ND & 400 & 5000 & ND & ND & ND & 400 & 300 & 300 & 1000 \\
\hline $\mathrm{FB}$ & 263 & ND & 6000 & 422 & 511 & 674 & 83 & 73 & 81 & 5000 \\
\hline OTA & ND & ND & 100 & ND & ND & ND & ND & ND & ND & 100 \\
\hline
\end{tabular}

${ }^{1} 0$, including $3 \%$ fresh fish oil and $0 \%$ oxidized fish oil; 1.5 , including $1.5 \%$ fresh fish oil and $1.5 \%$ oxidized fish oil; 3 , including $0 \%$ fresh fish oil and $3 \%$ oxidized fish oil. ${ }^{2}$ AFB1, aflatoxin B1; ZEA, zearalenone; DON, vomitoxin; FB, fumonisin; OTA, ochratoxin. ${ }^{3} \mathrm{ND}$ : not detected. Detection limit of AFB1 was $1.0 \mu \mathrm{g} / \mathrm{kg}$; Detection limit of ZEA was $5.0 \mu \mathrm{g} / \mathrm{kg}$; Detection limit of DON was $100 \mu \mathrm{g} / \mathrm{kg}$; Detection limit of FB was $50 \mu \mathrm{g} / \mathrm{kg}$; Detection limit of OTA was $5.0 \mathrm{\mu g} / \mathrm{kg} .{ }^{4}$ The data of limits on mycotoxins in maize and feed were from China Feed Hygiene Standard (GB 13078-2017).

\subsection{Growth Performance}

The effects of dietary aged maize and oxidized fish oil levels on growth performance of piglets are shown in Table 5. Aged maize had no significant effect on BW, ADFI, ADG and F/G of piglets ( $p>0.05)$. Dietary oxidized fish oil significantly decreased 14-28 d and 0-28 d ADG $(p<0.05)$, significantly increased 0-28 d F/G $(p<0.05)$, and tended to decrease 14-28 d ADFI of piglets $(p<0.10)$ compared to controls. There were no significant differences on the growth performance among the three normal maize groups $(p>0.05)$, while the $3 \%$ oxidized fish oil group significantly decreased 14-28 d ADFI and $0-28 \mathrm{~d}$ ADG, increased F/G of each stage compared to the $0 \%$ oxidized fish oil group of piglets fed with aged maize $(p<0.05)$. Maize $\times$ oil interaction showed a significant effect on $0-28 \mathrm{~d} F / G(p<0.05)$. 
Table 5. Effects of aged maize and oxidized fish oil levels on growth performance of weaning piglets.

\begin{tabular}{|c|c|c|c|c|c|c|c|c|c|c|}
\hline \multirow{2}{*}{ Items } & \multicolumn{3}{|c|}{ Normal Maize } & \multicolumn{3}{|c|}{ Aged Maize } & \multirow{2}{*}{ SEM } & \multicolumn{3}{|c|}{$p$-Value } \\
\hline & $0^{1}$ & 1.5 & 3 & 0 & 1.5 & 3 & & Maize $^{2}$ & Oil & Maize $\times$ Oil \\
\hline Initial BW ${ }^{3}(\mathrm{~kg})$ & 7.91 & 7.95 & 7.99 & 7.95 & 7.95 & 7.95 & 0.09 & 0.998 & 0.984 & 0.982 \\
\hline $14 \mathrm{~d} \mathrm{BW}(\mathrm{kg})$ & 11.61 & 11.56 & 11.43 & 11.86 & 11.37 & 11.17 & 0.20 & 0.882 & 0.686 & 0.863 \\
\hline $28 \mathrm{~d}$ BW (kg) & 17.59 & 17.34 & 16.94 & 18.06 & 16.98 & 16.10 & 0.28 & 0.612 & 0.227 & 0.703 \\
\hline \multicolumn{11}{|l|}{ Phase $10-14 \mathrm{~d}$} \\
\hline ADFI (g) & 437.76 & 440.41 & 409.64 & 445.51 & 397.55 & 417.55 & 14.38 & 0.767 & 0.725 & 0.731 \\
\hline $\operatorname{ADG}(\mathrm{g})$ & 264.69 & 257.96 & 245.48 & 279.59 & 244.90 & 230.61 & 10.06 & 0.836 & 0.417 & 0.807 \\
\hline $\mathrm{F} / \mathrm{G}$ & $1.68^{\mathrm{ab}}$ & $1.74^{\mathrm{ab}}$ & $1.67^{\mathrm{ab}}$ & $1.60^{\mathrm{b}}$ & $1.64^{\mathrm{ab}}$ & $1.84^{\mathrm{a}}$ & 0.03 & 0.950 & 0.284 & 0.124 \\
\hline \multicolumn{11}{|l|}{ Phase 2 14-28 d } \\
\hline ADFI (g) & $747.86^{a}$ & $740.20^{a}$ & $699.64^{a b}$ & $741.53^{a}$ & $707.76^{\mathrm{ab}}$ & $633.57^{b}$ & 14.05 & 0.207 & 0.073 & 0.678 \\
\hline ADG $(g)$ & $426.73^{a}$ & $412.76^{\mathrm{ab}}$ & $393.93^{a b}$ & $442.45^{\mathrm{a}}$ & $400.31^{\mathrm{ab}}$ & $351.84^{b}$ & 9.67 & 0.483 & 0.033 & 0.447 \\
\hline $\mathrm{F} / \mathrm{G}$ & $1.76^{\mathrm{ab}}$ & $1.79 \mathrm{ab}$ & $1.79 \mathrm{ab}$ & $1.69^{\mathrm{b}}$ & $1.77^{\mathrm{ab}}$ & $1.90^{\mathrm{a}}$ & 0.02 & 0.614 & 0.102 & 0.250 \\
\hline \multicolumn{11}{|l|}{ Overall 0-28 d } \\
\hline ADFI (g) & 592.81 & 590.31 & 554.64 & 593.52 & 552.70 & 516.67 & 12.97 & 0.347 & 0.220 & 0.782 \\
\hline ADG $(g)$ & $345.71^{a}$ & $335.36^{a b}$ & $319.70^{a b}$ & $355.92^{\mathrm{a}}$ & $322.60 \mathrm{ab}$ & $275.48^{b}$ & 8.61 & 0.347 & 0.043 & 0.415 \\
\hline $\mathrm{F} / \mathrm{G}$ & $1.72^{b}$ & $1.77^{\mathrm{b}}$ & $1.73^{\mathrm{b}}$ & $1.67^{\mathrm{b}}$ & $1.72^{b}$ & $1.89^{\mathrm{a}}$ & 0.02 & 0.540 & 0.026 & 0.024 \\
\hline
\end{tabular}

${ }^{1} 0$, including $3 \%$ fresh fish oil and $0 \%$ oxidized fish oil; 1.5 , including $1.5 \%$ fresh fish oil and $1.5 \%$ oxidized fish oil; 3, including $0 \%$ fresh fish oil and 3\% oxidized fish oil. ${ }^{2}$ Maize: normal maize or aged maize; Oil: $0 \%, 1.5 \%$ or $3 \%$ oxidized fish oil; maize $\times$ oil: maize $\times$ oxidized fish oil levels. ${ }^{3} \mathrm{BW}$, body weight; ADFI, average daily feed intake; ADG, average daily gain; F/G, feed/gain. ${ }^{a, b}$ In the same row, values with different letter superscripts mean significant difference $(p<0.05)$. 


\subsection{Diarrhea Incidence}

The effects of dietary aged maize and oxidized fish oil levels on diarrhea rate and diarrhea index of piglets are shown in Table 6. Aged maize tended to increase diarrhea index of piglets $(p<0.10)$. Dietary oxidized fish oil significantly increased diarrhea index of piglets $(p<0.05)$. No significant maize $\times$ oil interaction was observed on diarrhea rate and diarrhea index of piglets $(p>0.05)$.

Table 6. Effects of aged maize and oxidized fish oil levels on diarrhea rate and diarrhea index of weaning piglets.

\begin{tabular}{|c|c|c|c|c|c|c|c|c|c|c|}
\hline \multirow{2}{*}{ Items } & \multicolumn{3}{|c|}{ Normal Maize } & \multicolumn{3}{|c|}{ Aged Maize } & \multirow{2}{*}{ SEM } & \multicolumn{3}{|c|}{$p$-Value } \\
\hline & $0^{1}$ & 1.5 & 3 & 0 & 1.5 & 3 & & Maize $^{2}$ & Oil & Maize $\times$ Oil \\
\hline $0-28 \mathrm{~d}$ & & & & & & & & & & \\
\hline Diarrhea rate $(\%)$ & 0.51 & 1.02 & 3.06 & 1.02 & 3.57 & 2.55 & 0.63 & 0.318 & 0.296 & 0.842 \\
\hline Diarrhea index & 0.01 & 0.03 & 0.12 & 0.02 & 0.09 & 0.17 & 0.02 & 0.089 & 0.030 & 0.352 \\
\hline
\end{tabular}

${ }^{1} 0$, including $3 \%$ fresh fish oil and $0 \%$ oxidized fish oil; 1.5 , including $1.5 \%$ fresh fish oil and $1.5 \%$ oxidized fish oil; 3 , including $0 \%$ fresh fish oil and $3 \%$ oxidized fish oil. ${ }^{2}$ Maize: normal maize or aged maize; oil: $0 \%, 1.5 \%$ or $3 \%$ oxidized fish oil; maize $\times$ oil: maize $\times$ oxidized fish oil levels.

\subsection{Nutrient Digestibility}

The effects of dietary aged maize and oxidized fish oil levels on nutrient digestibility of piglets are shown in Table 7. Aged maize had no significant effect on dietary nutrient digestibility of piglets $(p>0.05)$. Dietary oxidized fish oil significantly decreased the ATTD of DM, EE and OM $(p<0.05)$ and tended to decrease the ATTD of CP $(p<0.10)$ compared to controls. Moreover, the $3 \%$ oxidized fish oil group significantly decreased the ATTD of CP compared to the $0 \%$ oxidized fish oil group when piglets fed with aged maize $(p<0.05)$. A significant maize $\times$ oil interaction was observed on the ATTD of ash $(p<0.05)$.

Table 7. Effects of aged maize and oxidized fish oil levels on nutrients apparent digestibility of weaning piglets.

\begin{tabular}{|c|c|c|c|c|c|c|c|c|c|c|}
\hline \multirow{2}{*}{ Items } & \multicolumn{3}{|c|}{ Normal Maize } & \multicolumn{3}{|c|}{ Aged Maize } & \multirow{2}{*}{ SEM } & \multicolumn{3}{|c|}{$p$-Value } \\
\hline & $0^{1}$ & 1.5 & 3 & 0 & 1.5 & 3 & & Maize $^{2}$ & Oil & Maize $\times$ Oil \\
\hline \multicolumn{11}{|l|}{$28 \mathrm{~d}$} \\
\hline $\mathrm{DM}^{3}(\%)$ & $82.96^{a}$ & $82.25^{a b}$ & $82.00^{a b}$ & $83.49^{a}$ & $81.38^{a b}$ & $79.84^{\mathrm{b}}$ & 0.35 & 0.207 & 0.023 & 0.257 \\
\hline EE (\%) & $78.16^{\mathrm{a}}$ & $75.39^{a b}$ & $72.27^{\mathrm{cd}}$ & $77.62^{a b}$ & $74.81^{b c}$ & $71.17^{\mathrm{d}}$ & 0.55 & 0.379 & $<0.001$ & 0.953 \\
\hline Ash (\%) & $51.94^{b c}$ & $52.01 \mathrm{bc}$ & $54.10^{\mathrm{ab}}$ & $57.92^{\mathrm{a}}$ & $54.22 \mathrm{ab}$ & $47.90^{c}$ & 0.77 & 0.619 & 0.066 & 0.002 \\
\hline OM (\%) & $85.02^{a}$ & $83.91^{a b}$ & $83.56^{a b}$ & $84.98^{a}$ & $82.95^{\mathrm{ab}}$ & $81.73^{b}$ & 0.34 & 0.141 & 0.013 & 0.516 \\
\hline $\mathrm{CP}(\%)$ & $77.38^{a b}$ & $76.07^{a b}$ & $76.23^{a b}$ & $78.49^{a}$ & $75.68^{a b}$ & $73.29^{b}$ & 0.60 & 0.533 & 0.096 & 0.384 \\
\hline
\end{tabular}

${ }^{1} 0$, including $3 \%$ fresh fish oil and $0 \%$ oxidized fish oil; 1.5 , including $1.5 \%$ fresh fish oil and $1.5 \%$ oxidized fish oil; 3 , including $0 \%$ fresh fish oil and 3\% oxidized fish oil. ${ }^{2}$ Maize: normal maize or aged maize; Oil: $0 \%, 1.5 \%$ or $3 \%$ oxidized fish oil; maize $\times$ oil: maize $\times$ oxidized fish oil levels. ${ }^{3} \mathrm{DM}$, dry matter; EE, crude fat; ash, crude ash; OM, organic matter; $\mathrm{CP}$, crude protein. ${ }^{\mathrm{a}, \mathrm{b}, \mathrm{c}}$ In the same row, values with different letter superscripts mean significant difference $(p<0.05)$.

\subsection{Antioxidant Capacity in Serum}

The effects of dietary aged maize and oxidized fish oil levels on antioxidant capacity in serum are shown in Table 8. Aged maize increased MDA concentration and decreased T-AOC activity in serum on both 14th and 28th days $(p<0.05)$, and showed a trend to decrease serum T-SOD activity and VE concentration on the 14th day $(p<0.10)$. Oxidized fish oil decreased T-AOC activity in serum on both the 14th and the 28th days $(p<0.05)$, and decreased serum T-SOD activity and VE concentration on the 28th day $(p<0.05)$, whereas increased serum MDA concentration on the 28th day $(p<0.05)$ and 14th day $(p<0.10)$ compared with fresh fish oil. No significant interaction between Maize $\times$ Oil was observed $(p>0.05)$. 
Table 8. Effects of aged maize and oxidized fish oil levels on antioxidant capacity in serum of weaning piglets.

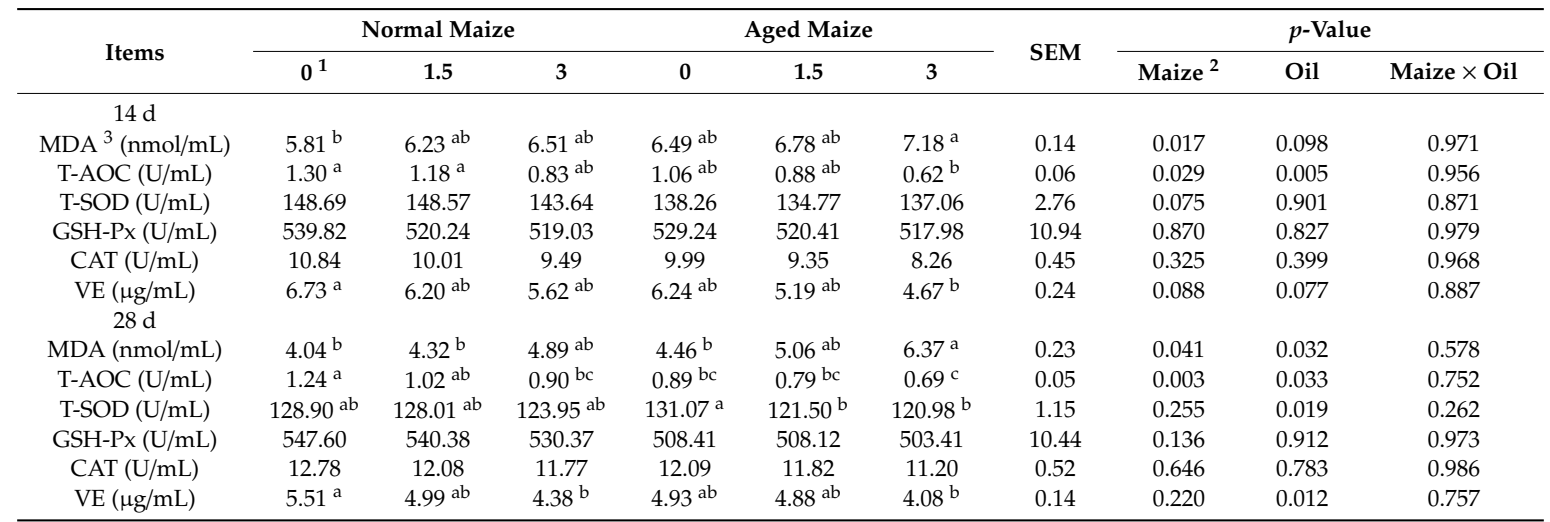

${ }^{1} 0$, including $3 \%$ fresh fish oil and $0 \%$ oxidized fish oil; 1.5 , including $1.5 \%$ fresh fish oil and $1.5 \%$ oxidized fish oil; 3, including $0 \%$ fresh fish oil and 3\% oxidized fish oil. ${ }^{2}$ Maize: normal maize or aged maize; Oil: $0 \%, 1.5 \%$ or $3 \%$ oxidized fish oil; Maize $\times$ Oil: maize $\times$ oxidized fish oil levels. ${ }^{3}$ MDA, malondialdehyde; T-AOC, total antioxidant capacity; T-SOD, total superoxide dismutase; GSH-Px, glutathione peroxidase; CAT, catalase; VE, vitamin E. ${ }^{a, b, c}$ In the same row, values with different letter superscripts mean significant difference $(p<0.05)$.

\subsection{Nutrient Transporter-Related Gene Expression in Jejunum Mucosa}

The effects of dietary aged maize and oxidized fish oil levels on nutrient transporter-related gene expression in jejunum mucosa of piglets were shown in Table 9. Aged maize significantly decreased GLUT2 mRNA expression in jejunal mucosa of piglets $(p<0.05)$ compared to controls. Dietary oxidized fish oil showed a trend to decrease SGLT1 mRNA expression in jejunal mucosa of piglets $(p<0.10)$. The 3\% oxidized fish oil group significantly decreased GLUT2 and SGLT1 mRNA expression in jejunal mucosa relative to $0 \%$ oxidized fish oil group of piglets fed with aged maize $(p<0.05)$. Maize $\times$ oil interaction effects showed no significant interactions on nutrient transporter-related gene expression in jejunum mucosa of piglets $(p>0.05)$.

Table 9. Effects of aged maize and oxidized fish oil levels on nutrient transporter-related gene expression in jejunum mucosa of weaning piglets.

\begin{tabular}{|c|c|c|c|c|c|c|c|c|c|c|}
\hline Items & \multicolumn{3}{|c|}{ Normal Maize } & \multicolumn{3}{|c|}{ Aged Maize } & SEM & \multicolumn{3}{|c|}{$p$-Value } \\
\hline $28 \mathrm{~d}$ & & & & & & & & & & \\
\hline GLUT2 & $1.00^{\mathrm{a}}$ & $0.89^{a b}$ & $1.03^{\mathrm{a}}$ & $0.94^{\mathrm{a}}$ & $0.72^{a b}$ & $0.42^{b}$ & 0.07 & 0.041 & 0.300 & 0.230 \\
\hline
\end{tabular}

${ }^{1} 0$, including $3 \%$ fresh fish oil and $0 \%$ oxidized fish oil; 1.5 , including $1.5 \%$ fresh fish oil and $1.5 \%$ oxidized fish oil; 3 , including $0 \%$ fresh fish oil and 3\% oxidized fish oil. ${ }^{2}$ Maize: normal maize or aged maize; oil: $0 \%, 1.5 \%$ or $3 \%$ oxidized fish oil; maize $\times$ oil: maize $\times$ oxidized fish oil levels. ${ }^{3}$ SGLT1, Na+ dependent glucose transporter; GLUT2, glucose transporter $2 ;{ }^{a}, \mathrm{~b}$ In the same row, values with different letter superscripts mean significant difference $(p<0.05)$.

\subsection{Inflammation-Related Gene Expression in Jejunum Mucosa}

The effects of dietary aged maize and oxidized fish oil levels on inflammation-related gene expression in jejunum mucosa of piglets were shown in Table 10. Aged maize showed a trend to increase TNF- $\alpha$ and IL-6 mRNA expression in jejunal mucosa of piglets $(p<0.10)$. Dietary oxidized fish oil also showed a tend to increase IL-6 mRNA expression in jejunal mucosa of piglets $(p<0.10)$. No significant maize $\times$ oil interaction effects were observed on inflammation-related gene expression in jejunum mucosa of piglets $(p>0.05)$. 
Table 10. Effects of aged maize and oxidized fish oil levels on inflammation-related gene expression in jejunum mucosa of weaning piglets.

\begin{tabular}{|c|c|c|c|c|c|c|c|c|c|c|}
\hline \multirow{2}{*}{ Items } & \multicolumn{3}{|c|}{ Normal Maize } & \multicolumn{3}{|c|}{ Aged Maize } & \multirow{2}{*}{ SEM } & \multicolumn{3}{|c|}{$p$-Value } \\
\hline & $0^{1}$ & 1.5 & 3 & 0 & 1.5 & 3 & & Maize $^{2}$ & Oil & Maize $\times$ Oil \\
\hline $28 \mathrm{~d}$ & & & & & & & & & & \\
\hline$T N F-\alpha^{3}$ & 1.00 & 1.35 & 1.52 & 1.51 & 1.75 & 1.82 & 0.10 & 0.059 & 0.268 & 0.917 \\
\hline$I L-1 \beta$ & 1.00 & 1.11 & 1.29 & 1.24 & 1.35 & 1.69 & 0.12 & 0.238 & 0.442 & 0.953 \\
\hline$I L-6$ & $1.00^{\mathrm{b}}$ & $1.18^{\mathrm{ab}}$ & $1.64^{\mathrm{ab}}$ & $1.46^{\mathrm{ab}}$ & $1.59^{a b}$ & $1.93^{\mathrm{a}}$ & 0.10 & 0.060 & 0.076 & 0.936 \\
\hline$I L-10$ & 1.00 & 0.89 & 0.72 & 0.82 & 0.54 & 0.44 & 0.09 & 0.167 & 0.377 & 0.927 \\
\hline
\end{tabular}

\subsection{Tight Junctions Protein and Mucins-Related Gene Expression in Jejunum Mucosa}

The effects of dietary aged maize and oxidized fish oil levels on tight junction proteins and mucins-related gene expression in jejunal mucosa were shown in Table 11. Aged maize had no significantly effects on ZO-1, OCLD, CLDN1, MUC1 and MUC2 mRNA expression in jejunal mucosa of piglets $(p>0.05)$. Dietary oxidized fish oil significantly decreased MUC2 mRNA expression in jejunal mucosa of piglets $(p<0.05)$ compared to controls. No significant interaction between maize $\times$ oil were observed on tight junction proteins and mucins-related gene expression in piglets $(p>0.05)$.

Table 11. Effects of aged maize and oxidized fish oil levels on tight junctions protein and mucins-related gene expression in jejunum mucosa of weaning piglets.

\begin{tabular}{|c|c|c|c|c|c|c|c|c|c|c|}
\hline \multirow{2}{*}{ Items } & \multicolumn{3}{|c|}{ Normal Maize } & \multicolumn{3}{|c|}{ Aged Maize } & \multirow{2}{*}{ SEM } & \multicolumn{3}{|c|}{$p$-Value } \\
\hline & $0^{1}$ & 1.5 & 3 & 0 & 1.5 & 3 & & Maize $^{2}$ & Oil & Maize $\times$ Oil \\
\hline $28 \mathrm{~d}$ & & & & & & & & & & \\
\hline $\mathrm{ZO}-1^{3}$ & 1.00 & 0.64 & 0.77 & 1.05 & 0.80 & 0.71 & 0.08 & 0.782 & 0.288 & 0.886 \\
\hline OCLN & 1.00 & 1.03 & 0.92 & 0.91 & 0.98 & 0.95 & 0.05 & 0.736 & 0.872 & 0.905 \\
\hline CLDN1 & 1.00 & 1.14 & 0.83 & 1.01 & 1.04 & 0.95 & 0.05 & 0.932 & 0.301 & 0.701 \\
\hline MUC1 & 1.00 & 0.86 & 0.85 & 1.12 & 0.82 & 0.72 & 0.10 & 0.922 & 0.429 & 0.844 \\
\hline MUC2 & $1.00^{\mathrm{a}}$ & $0.70^{a b}$ & $0.69^{a b}$ & $0.87^{a b}$ & $0.73^{a b}$ & $0.52^{b}$ & 0.05 & 0.378 & 0.043 & 0.707 \\
\hline
\end{tabular}

${ }^{1} 0$, including $3 \%$ fresh fish oil and $0 \%$ oxidized fish oil; 1.5 , including $1.5 \%$ fresh fish oil and $1.5 \%$ oxidized fish oil; 3, including $0 \%$ fresh fish oil and 3\% oxidized fish oil. ${ }^{2}$ Maize: normal maize or aged maize; oil: $0 \%, 1.5 \%$ or $3 \%$ oxidized fish oil; maize $\times$ oil: maize $\times$ oxidized fish oil levels. ${ }^{3}$ ZO-1, Zonulaoccludens 1 ; OCLN, Occludin; CLDN1, Claudin 1; MUC1, Mucin1; MUC2, Mucin2. ${ }^{a}, \mathrm{~b}$ In the same row, values with different letter superscripts mean significant difference $(p<0.05)$.

\section{Discussion}

In livestock production, numerous factors can induce oxidative stress and result in suboptimal health conditions of livestock and a reduction in production efficiency. A huge amount of maize used for feed production had been stored for a long time. Therefore, it is important to explore the effects of aged maize on piglets. Zhu, et al. [34] showed that $30 \%$ of aged maize was used to replace the normal maize significantly reduced ADG and final body weight of meat ducks. However, previous studies have reported that long-term storage of maize didn't affect the growth of rats or broilers [12,13]. In order to further assess the effects of aged maize on the health of piglets, the present study was conducted to investigate an additional challenge with oxidized fish oil to determine if it would exacerbate the negative effect of aged maize on piglets. In our study, dietary aged maize had no significant effects on growth performance and nutrient digestibility of piglets, while dietary oxidized fish oil reduced growth performance and nutrient digestibility, and increased diarrhea index of piglets. This is consistent with previous results that oxidized fat significantly reduced the growth performance of piglets [23,35]. The reason may be that, on the one hand, lipid peroxidation products affect the quality of the diet and 
reduce its digestibility [36]. Alternatively, products of lipid peroxidation may cause certain pathological damage to the gastrointestinal tract of pigs, or may cause changes in cell membrane function [37-39]. Altered cell membrane function may in turn reduce feed digestibility in piglets leading to diarrhea and ultimately affect the normal growth and development. Further, we found that dietary oxidized fish oil tended to decrease 14-28 d ADFI of piglets, maize $\times$ oil interaction had a significant effect on $0-28 \mathrm{~d}$ $\mathrm{F} / \mathrm{G}$ of piglets, in that the additional oxidized fish oil challenge exacerbated the effects of aged maize on growth performance of piglets.

To further explore the effects of aged maize and oxidized fish oil on absorption of nutrients, we investigated the relative mRNA expression of SGLT1 and GLUT2 following feeding of these nutrients to piglets. SGLT1, an apical intestinal transporter, is responsible for the majority of luminal glucose transport across intestinal epithelium, and is the rate-limiting step for absorption of dietary glucose $[40,41]$. GLUT2, a key transporter located at the basolateral membrane of the enterocyte, provides a glucose channel on enterocytes as a part of the intestinal glucose absorption system [42]. Therefore, the relative mRNA expression of SGLT1 and GLUT2 are closely related to the intestinal absorption of glucose. In this study, dietary aged maize significantly inhibited the relative mRNA expression of GLUT2 and oxidized fish oil tended to decrease the relative mRNA expression of SGLT1 in jejunal mucosa of piglets. Oxidized fish oil had no significant effect on the relative mRNA expression of SGLT1 and GLUT2 of piglets fed with normal maize, however the 3\% oxidized fish oil group significantly decreased GLUT2 and SGLT1 mRNA expression in jejunal mucosa relative to $\%$ oxidized fish oil group of piglets fed with aged maize. These results suggested that aged maize had no significant effect on the nutrient transport under normal conditions and thus did not affect growth performance of piglets. However, piglets given an additional oxidative stress showed further reduced production compared to piglets fed normal maize. In the presence of oxidized fish oil, aged maize significantly reduced the relative mRNA expression of GLUT2 and tended to reduce the relative mRNA expression of SGLT1. These observations indicate that the transport and absorption of glucose in the small intestine is negatively impacted by oxidized oil when additionally fed aged maize, that may lead to increased diarrhea and ultimately reducing the growth performance of piglets.

Reactive oxygen species (ROS) are always in an internal dynamic equilibrium state. When exogenous oxidative stress exceeds the resistance ability of the organism itself, which will reduce the antioxidant capacity of the organism and lead to oxidative damage [43]. MDA is a product of lipid peroxidation and its level is frequently used as a direct marker of lipid oxidative damage caused by ROS [44]. Antioxidant systems in organisms include enzymatic defense systems (CAT, GSH-Px, and SOD) and non-enzymatic defense systems (GSH, VE, and VC) that work together to eliminate excess free radicals to prevent oxidative damage [45,46]. Liu et al. [7] showed that broilers fed maize that had been stored for long periods of time had reduced serum GSH-Px and T-SOD activities and significantly increased serum MDA content compared to broiler-fed maize that had been stored for a short period of time. Our study supported those findings in that aged maize in piglet diet increased serum MDA content and decreased serum T-AOC, T-SOD activities and VE content compared to piglets fed maize stored for a short period of time. The reduction of antioxidant enzyme levels in aged maize and the accumulation of large amounts of ROS may have further reduced the antioxidant capacity of the diet. Dietary oxidized fish oil increased serum MDA content and reduced serum T-AOC activity and VE content in piglets. Studies by others found that dietary oxidized oil reduced the antioxidant capacity of pigs $[47,48]$. In our study, we also demonstrated that piglets fed aged maize + $3 \%$ oxidized fish oil group had the lowest antioxidant capacity of all treatment groups, which suggested that oxidized fish oil further decreased the antioxidant capacity when piglets fed with aged maize.

Oxidative stress is often accompanied by inflammation. Pro-inflammatory factors (such as $T N F-\alpha, I L-1 \beta, I L-6)$ and anti-inflammatory factors (such as $I L-10)$ that play crucial roles in the integrity of intestinal mucosal and tight junctional barriers [49]. Varady, et al. [50] found that oxidized fat markedly increased nuclear concentration of NF- $\mathrm{kB}$ in intestinal mucosa of mice. NF- $\mathrm{kB}$ plays a key role in regulating the expression of pro-inflammatory and anti-inflammatory factors in 
tissues. Manar, et al. [51] demonstrated that animals fed an oxidized diet showed enhanced plasma inflammatory markers (IL-6 and MCP-1) and increased activation of NF- $\mathrm{KB}$ in the small intestine as well as decreased Paneth cell number compare to animals fed an unoxidized diet. These data suggested that the inflammatory response of the body was due to the oxidized oil in the diet which caused excessive ROS accumulation, thereby activating NF- $\kappa B$, that in turn increased the expression of related pro-inflammatory factors. Similarly, in our study we found that feeding aged maize increased TNF- $\alpha$ and IL-6 mRNA expression and the addition of oxidized fish oil in the diet increased IL-6 mRNA expression in jejunal mucosa. All of which suggested that aged maize and oxidized fish oil elicited different degrees of jejunal inflammation in piglets. However, the specific inflammatory response induced by lipid peroxidation in aged maize and oxidized fish oil still needs further study.

Accumulating evidence has confirmed that inflammation is an important factor in intestinal barrier disruption [52]. Al and Boivin [53] found that cytokines could change the structure of tight junctions and modulate the expression of genes that code for tight junction proteins in mammals. Huang [54] showed that oxidized fish oil significantly decreased the relative expression of Claudin-3, Claudin-15a, ZO-1, ZO-2 and ZO-3 mRNAs in the intestinal mucosa of grass carp, while OCLN mRNA expression was also slightly decreased. In our current study, we found that aged maize and oxidized fish oil had no significant effect on the mRNA expression of ZO-1, CLDN1 and OCLN in jejunal mucosa of piglets. Liu, et al. [55] reported that feeding weaned piglet diets that contained $10 \%$ thermally oxidized lipid for $38 \mathrm{~d}$, appeared to impair oxidative status but had little influence on gut barrier, implying that pigs were relatively resilient to certain levels of lipid oxidation. The mucus layer is the first defense barrier against pathogen invasion in the gastrointestinal tract and an important part of the chemical barrier. Mucin proteins are a primary part of intestinal mucus that primarily includes MUC1 and MUC2 [56,57]. In our present study, dietary oxidized fish oil significantly reduced MUC2 mRNA expression in the jejunal mucosa of piglets, which suggests that oxidized fish oil damages the intestinal chemical barrier of piglets.

\section{Conclusions}

In conclusion, the combination of aged maize with oxidized fish oil caused sufficient dietary stress that led to increased diarrhea and decreased growth performance due to reduce the antioxidant capacity, enhance the mRNA expressions of inflammatory factors and lead to inflammation in jejunal mucosa, inhibit the mRNA expressions of nutrient transporter and further reducing the apparent digestibility of nutrients. Either aged maize or oxidized fish oil alone did not cause sufficient digestive distress to produce diarrhea or impact growth performance.

Author Contributions: Funding acquisition, B.Y.; investigation, B.L., D.C., G.T., P.Z., J.H., X.M., Y.L., J.L., J.Y. and Z.H.; methodology, B.Y.; project administration, B.Y.; writing-review and editing, B.L. and B.Y.

Funding: This research was funded by the Ministry of Science and Technology of China, Grant No.2014BAD13B01 and Science and Technology Basic Work Special Project of China, Grant No. 2014FY111000-4.

Acknowledgments: The authors would like to thank to Quyuan Wang and Huifen Wang (the Institute of Animal Nutrition, Sichuan Agricultural University) for their collaboration during the pig experiments. The authors also wish to thank Gregory S. Fraley and Amanda Bentley (Hope College, Biology Department, Holland, MI USA) for their critical comments during the preparation of this manuscript.

Conflicts of Interest: The authors declare no conflict of interest.

\section{References}

1. Kil, D.Y.; Park, C.S.; Son, A.R.; Ji, S.Y.; Kim, B.G. Digestibility of crude protein and amino acids in corn grains from different origins for pigs. Anim. Feed Sci. Technol. 2014, 196, 68-75. [CrossRef]

2. Rehman, Z.U. Storage effects on nutritional quality of commonly consumed cereals. Food Chem. 2006, 95, 53-57. [CrossRef] 
3. Setiawan, S.; Widjaja, H.; Rakphongphairoj, V. Effects of drying conditions of corn kernels and storage at an elevated humidity on starch structures and properties. J. Agric. Food Chem. 2010, 58, 12260-12267. [CrossRef] [PubMed]

4. Salman, H.; Copeland, L. Effect of storage on fat acidity and pasting characteristics of wheat flour. Cereal Chem. 2007, 84, 600-606. [CrossRef]

5. Zhang, Y.R.; Zhou, X.Q.; Yong, Z. Research on membrane lipid peroxidation and physiological parameters of storage maize. Sci. Agric. Sin. 2008, 41, 3410-3414. [CrossRef]

6. Rios-Gonzalez, K.; Erdei, L.; Lips, S.H. The activity of antioxidant enzymes in maize and sunflower seedlings as affected by salinity and different nitrogen sources. Plant Sci. 2002, 162, 0-930. [CrossRef]

7. Liu, B.Y.; He, Y.Y.; Yin, D.F.; Xia, Z.F.; Yuan, J.M. Corn at different storage periods affects serum antioxidant function of broilers. Chin. J. Anim. Nutr. 2013, 25, 1077-1084.

8. Yin, D.; Yuan, J.; Guo, Y.; Chiba, L.I. Effect of storage time on the characteristics of corn and efficiency of its utilization in broiler chickens. Anim. Nutr. 2017, 3, 252-257. [CrossRef]

9. Mu, Y.; Zhang, K.; Bai, S.; Wang, J.P.; Zeng, Q.; Ding, X. Effects of vitamin e supplementation on performance, serum biochemical parameters and fatty acid composition of egg yolk in laying hens fed a diet containing ageing corn. J. Anim. Physiol. Anim. Nutr. 2018, 103, 135-145. [CrossRef]

10. Qamar, S.H.; Zeng, Q.; Ding, X. Effect of oil supplementation on growth performance, meat quality and antioxidative ability in meat ducks fed a diet containing aging corn. Int. J. Agric. Biol. 2019, 21, 201-208. [CrossRef]

11. Mitchell, H.H.; Beadles, J.R. The effect of storage on the nutritional qualities of the proteins of wheat, corn and soybeans. J. Nutr. 1949, 39, 463-484. [CrossRef] [PubMed]

12. Cabell, C.A.; Ellis, N.R. Feeding value of stored corn. J. Anim. Sci. 1955, 14, 1167-1173. [CrossRef]

13. Bartov, I. Effect of storage duration on the nutritional value of corn kernels for broiler chicks. Poult. Sci. 1996, 75, 1524-1527. [CrossRef]

14. Sun, D. The problem of jaundice caused by the use of aged corn in china's feed enterprises from 2016 to 2017. Chin. J. Anim. Sci. 2017, 53, 147-151.

15. Rosero, D.S.; Odle, J.; Moeser, A.J.; Boyd, R.D.; van Heugten, E. Peroxidised dietary lipids impair intestinal function and morphology of the small intestine villi of nursery pigs in a dose-dependent manner. Br. J. Nutr. 2015, 114, 1985-1992. [CrossRef]

16. Fontagné-Dicharry, S.; Larroquet, L.; Dias, K.; Cluzeaud, M.; Heraud, C.; Corlay, D. Effects of dietary oxidized fish oil supplementation on oxidative stress and antioxidant defense system in juvenile rainbow trout (Oncorhynchus mykiss). Fish Shellfish. Immunol. 2017, 74, 43-51. [CrossRef] [PubMed]

17. Zhang, Y.; Yu, B.; Yu, J.; Zheng, P.; Huang, Z.; Luo, Y.; Luo, J.; Mao, X.; Yan, H.; He, J.; et al. Butyrate promotes slow-twitch myofiber formation and mitochondrial biogenesis in finishing pigs via inducing specific microRNAs and PGC-1 $\alpha$ expression. J. Anim. Sci. 2019, 97, 3180-3192. [CrossRef]

18. AOAC. Official Methods of Analysis of AoAC International, 18th ed.; AOAC: Washington, DC, USA, 2007.

19. Qiang, Z.; Selomulya, C.; Hua, X.; Xiao, D.C.; Xiang, L.; Wang, S.; Bai, C.; Peng, H.; Qiang, Z.; Sun, W. Rice dreg protein as an alternative to soy protein isolate: Comparison of nutritional properties. Int. J. Food Prop. 2014, 17, 1791-1804. [CrossRef]

20. Querijero, B.V.L.; Teshima, S.; Koshio, S.; Ishikawa, M. Utilization of monounsaturated fatty acid (18:1n-9, oleic acid) by freshwater prawn macrobrachium rosenbergii (de man) juveniles. Aquac. Nutr. 2015, 3, 127-139. [CrossRef]

21. MOH; SAC. Guidelines for evaluation of maize storage character. In GB/T 20570-2015; Ministry of Health and Standardization Administration of China: Beijing, China, 2015.

22. NRC. Nutrient Requirements of Swine; NRC: Washington DC, USA, 2012; Volume 44.

23. Yuan, S.B.; Chen, D.W.; Zhang, K.Y.; Yu, B. Effects of oxidative stress on growth performance, nutrient digestibilities and activities of antioxidative enzymes of weanling pigs. Asian-Australas. J. Anim. Sci. 2007, 20, 1600-1605. [CrossRef]

24. MOH; SAC. Determination of peroxide value in food. In GB 5009.227-2016; Ministry of Health and Standardization Administration of China: Beijing, China, 2016.

25. $\mathrm{MOH}$; SAC. Determination of aflatoxins, zearalenone and $\mathrm{t}-2$ in feeds-liquid chromatography-tandem mass spectrometry. In NY/T 2071-2011; Ministry of Health and Standardization Administration of China: Beijing, China, 2011. 
26. MOH; SAC. Determination of deoxynivalenol in feeds-high performance liquid chromatography with immunoaffinity column clean-up. In GB/T 30956-2014; Ministry of Health and Standardization Administration of China: Beijing, China, 2014.

27. MOH; SAC. Determination of fumonsins in feeds. In NY/T 1970-2010; Ministry of Health and Standardization Administration of China: Beijing, China, 2010.

28. MOH; SAC. Determination of ochratoxin a in feeds-high performance liquid chromatography with immunoaffinity column clean-up. In GB/T 30957-2014; Ministry of Health and Standardization Administration of China: Beijing, China, 2014.

29. Raymond, S.L.; Smith, T.K.; Swamy, H.V.L.N. Effects of feeding a blend of grains naturally contaminated with fusarium mycotoxins on feed intake, serum chemistry, and hematology of horses, and the efficacy of a polymeric glucomannan mycotoxin adsorbent. J. Anim. Sci. 2003, 81, 2123-2130. [CrossRef] [PubMed]

30. Yuan, L.; Kang, S.Y.; Ward, L.A.; To, T.L.; Saif, L.J. Antibody-secreting cell responses and protective immunity assessed in gnotobiotic pigs inoculated orally or intramuscularly with inactivated human rotavirus. J. Virol. 1998, 72, 330-338. [CrossRef]

31. Pekel, A.Y.; Horn, N.L.; Adeola, O. The efficacy of dietary xylanase and phytase in broiler chickens fed expeller-extracted camelina meal. Poultry Sci. 2017, 96, pew183. [CrossRef] [PubMed]

32. Pfaffl, M.W.; Hageleit, M. Validities of mRNA quantification using recombinant RNA and recombinant DNA external calibration curves in real-time RT-PCR. Nucleic Acids Res. 2001, 23, 275-282. [CrossRef]

33. MOH; SAC. China feed hygiene standard. In GB 13078-2017; Ministry of Health and Standardization Administration of China: Beijing, China, 2017.

34. Zhu, Z.P.; Wang, Y.M.; Ding, Y. Effects of aged corn on growth performance, serum antioxidant activity and immune organ indexes of meat ducks. Chin. J. Anim. Husb. 2018, 54, 76-79.

35. Lu, T.; Harper, A.F.; Zhao, J.; Estienne, M.J.; Dalloul, R.A. Supplementing antioxidants to pigs fed diets high in oxidants: I. Effects on growth performance, liver function, and oxidative status. J. Anim. Sci. 2014, 92, 5455-5463. [CrossRef] [PubMed]

36. Liu, P.; Chen, C.; Kerr, B.J.; Weber, T.E.; Johnston, L.J.; Shurson, G.C. Influence of thermally oxidized vegetable oils and animal fats on growth performance, liver gene expression, and liver and serum cholesterol and triglycerides in young pigs. J. Anim. Sci. 2014, 92, 2960-2970. [CrossRef] [PubMed]

37. Comporti, M. Lipid peroxidation. Biopathological significance. Mol. Aspects Med. 1993, 14, $199-207$. [CrossRef]

38. Witz, G. Biological interactions of alpha, beta-unsaturated aldehydes. Free Radic. Biol. Med. 1989, 7, $333-349$. [CrossRef]

39. Overholt, M.F.; Dilger, A.C.; Boler, D.D.; Kerr, B.J. Influence of feeding thermally peroxidized soybean oil on growth performance, digestibility, and gut integrity in finishing pigs. J. Anim. Sci. 2018, 96, 2789-2803. [CrossRef] [PubMed]

40. Wright, E.M.; Martín, M.G.; Eric, T. Intestinal absorption in health and disease-Sugars. Best Pract. Res. Clin. Gastroenterol. 2003, 17, 943-956. [CrossRef]

41. Zhang, S.; Yang, Q.; Ren, M.; Qiao, S.; He, P.; Li, D.; Zeng, X. Effects of isoleucine on glucose uptake through the enhancement of muscular membrane concentrations of glut1 and glut 4 and intestinal membrane concentrations of nat/glucose co-transporter 1 (sglt-1) and glut2. Br. J. Nutr. 2016, 116, 593-602. [CrossRef] [PubMed]

42. Jones, H.F.; Butler, R.N.; Brooks, D.A. Intestinal fructose transport and malabsorption in humans. Am. J. Physiol. Gastrointest. Liver Physiol. 2011, 300, 202-206. [CrossRef] [PubMed]

43. Glade, M.J.; Meguid, M.M. A glance at ... telomeres, oxidative stress, antioxidants, and biological aging. Nutrition 2015, 31, 1447-1451. [CrossRef] [PubMed]

44. Placer, Z.A.; Cushman, L.L.; Johnson, B.C. Estimation of product of lipid peroxidation (malonyl dialdehyde) in biochemical systems. Anal. Biochem. 1966, 16, 359-364. [CrossRef]

45. Kim, M.H.; Lee, E.J.; Cheon, J.M.; Nam, K.J.; Oh, T.H.; Kim, K.S. Antioxidant and hepatoprotective effects of fermented red ginseng against high fat diet-induced hyperlipidemia in rats. Lab. Anim. Res. 2016, 32, 217-223. [CrossRef] [PubMed]

46. Kumar, S.; Sharma, U.K.; Sharma, A.K.; Pandey, A.K. Protective efficacy of solanum xanthocarpum root extracts against free radical damage: Phytochemical analysis and antioxidant effect. Cell Mol. Biol. (Noisy-le-Grand) 2012, 58, 174-181. [CrossRef] 
47. Lindblom, S.C.; Gabler, N.K.; Dilger, R.N.; Olson, Z.F.; Loving, C.L.; Kerr, B.J. Influence of feeding thermally peroxidized soybean oil on oxidative status in growing pigs. J. Anim. Sci. 2017, 95, 545-557. [CrossRef]

48. Boler, D.D.; Fernándezdueñas, D.M.; Kutzler, L.W.; Zhao, J.; Harrell, R.J.; Campion, D.R.; Mckeith, F.K.; Killefer, J.; Dilger, A.C. Effects of oxidized corn oil and a synthetic antioxidant blend on performance, oxidative status of tissues, and fresh meat quality in finishing barrows. J. Anim. Sci. 2012, 90, 5159-5169. [CrossRef]

49. O'Neill, L.A.J.; Kaltschmidt, C. Nf-kb: A crucial transcription factor for glial and neuronal cell function. Trends Neurosci. 1997, 20, 252-258. [CrossRef]

50. Varady, J.; Eder, K.; Ringseis, R. Dietary oxidized fat activates the oxidative stress-responsive transcription factors NF-кB and Nrf2 in intestinal mucosa of mice. Eur. J. Nutr. 2011, 50, 601-609. [CrossRef] [PubMed]

51. Manar, A.; Christophe, O.S.; Anne, M.; Cyrille, D.; Pascale, P.; Bérengère, B.; Grégory, P.; Emmanuelle, L.; Marie-Agnès, C.; Monique, E. Dietary oxidized n-3 pufa induce oxidative stress and inflammation: Role of intestinal absorption of 4-hhe and reactivity in intestinal cells. J. Lipid Res. 2012, 53, 2069-2080. [CrossRef]

52. Anderson, J.M.; Van Itallie, C.M. Tight junctions and the molecular basis for regulation of paracellular permeability. Am. J. Physiol. 1995, 269, 467-475. [CrossRef] [PubMed]

53. Al, S.R.; Boivin, M.T. Mechanism of cytokine modulation of epithelial tight junction barrier. Front. Biosci. 2009, 14, 2765-2778. [CrossRef]

54. Huang, Y. The study on damage of intestinal mucosa barrier structure with oxidized fish oil diets in. J. Fish. China 2015, 79, 1620-1631. [CrossRef]

55. Liu, P.; Kerr, B.J.; Weber, T.E.; Chen, C.; Johnston, L.J.; Shurson, G.C. Influence of thermally oxidized vegetable oils and animal fats on intestinal barrier function and immune variables in young pigs. J. Anim. Sci. 2014, 92, 2971-2979. [CrossRef]

56. Lindén, S.K.; Florin, T.H.; Mcguckin, M.A. Mucin dynamics in intestinal bacterial infection. PLoS ONE 2008, 3, e3952. [CrossRef]

57. Liu, J.B.; Zhang, Y.; Li, Y.; Yan, H.L.; Zhang, H.F. L-Tryptophan Enhances Intestinal Integrity in Diquat-Challenged Piglets Associated with Improvement of Redox Status and Mitochondrial Function. Animals 2019, 9, 266. [CrossRef]

(C) 2019 by the authors. Licensee MDPI, Basel, Switzerland. This article is an open access article distributed under the terms and conditions of the Creative Commons Attribution (CC BY) license (http://creativecommons.org/licenses/by/4.0/). 